\title{
BAKTERI PATOGEN DALAM SPONS CUCI PIRING PADA PENJUAL MAKANAN DI PASAR MARGAHAYU, BEKASI TIMUR
}

\author{
Yola Violita Agustin ${ }^{1}$, Noor Andryan Ilsan ${ }^{2 *}$, Maulin Inggraini ${ }^{3}$ \\ 1. Program Studi DIII Analis Kesehatan, STIKes Mitra Keluarga, Bekasi-Indonesia \\ 2. Program Studi DIII Analis Kesehatan, STIKes Mitra Keluarga, Bekasi-Indonesia \\ 3. Program Studi DIII Analis Kesehatan, STIKes Mitra Keluarga, Bekasi-Indonesia \\ *Korespondensi: Noor Andryan Ilsan | STIKes Mitra Keluarga| noorandryanilsan@ gmail.com
}

\begin{abstract}
Abstrak
Pendahuluan: Makanan dan minuman yang tidak memenuhi persyaratan kesehatan jika dikonsumsi akan menimbulkan gangguan kesehatan seperti diare, kolera, disentri, demam tifoid dan keracunan makanan. Menurut data Kemenkes tahun 2017 kasus diare pada tahun 2016 dengan Case Fatality Rate (CFR) mencapai 3.04\% dengan 6 orang meninggal dari 198 kasus. Kebersihan peralatan makan merupakan salah satu aspek dalam hygiene dan sanitasi makanan. Proses pencucian peralatan makan yang benar akan berdampak pada hygiene dan sanitasi yang baik. Spons cuci piring umumnya digunakan untuk menghilangkan sisa makanan. Sisa makanan yang terdapat pada spons akan mendukung lingkungan bakteri untuk tumbuh. Spons yang terkontaminasi dapat mengkontaminasi peralatan makan, sehingga menyebabkan penularan penyakit bawaan makanan. Studi kasus di Amerika Serikat menunjukkan bahwa terjadi hampir 38.6 juta kasus penyakit akibat penyebaran penyakit bawaan makanan. Penelitian ini bertujuan untuk mengetahui keberadaan bakteri patogen serta jenis bakteri patogen yang terdapat pada spons cuci piring pada penjual makanan.

Metode: Identifikasi bakteri patogen dilakukan pada 10 spons cuci piring yang digunakan penjual makanan di Pasar Margahayu. Identifikasi bakteri menggunakan pewarnaan Gram dan uji biokimia.

Hasil: Jenis bakteri patogen yang teridentifikasi adalah Escherichia coli, Staphylococcus aureus, Pseudomonas aeroginosa, Enterobacter aerogenes, dan Proteus sp. Persentase isolat yang ditemukan adalah $80 \%$ spons mengandung S. aureus, 70\% mengandung E. aerogenes, 20\% mengandung E.coli, 20\% mengandung P.aeroginosa, dan 10\% mengandung Proteus sp.

Kesimpulan: sampel spons cuci piring yang telah dilakukan pewarnaan Gram dan uji biokimia menunjukkan kecurigaan terhadap koloni berwarna putih transparan adalah Proteus sp. koloni putih transparan bulat kecil adalah Enterobacter aerogenes, putih bulat besar adalah Escherichia coli, putih bulat kecil adalah Pseudomonas aeroginosa, koloni merah pada media SSA adalah Enterobacter aerogenes, dan koloni putih dengan zona kuning adalah Staphylococcus aureus.
\end{abstract}

Kata Kunci: Bakteri Patogen, Spons cuci piring, Uji biokimia

Diterima 12 Agustus 2019; Accepted 30 Desember 2019

\section{PENDAHULUAN}

Makanan dan minuman merupakan suatu hal yang sangat penting di dalam kehidupan manusia. Makanan dan minuman berfungsi memberi tenaga atau energi bagi tubuh. Makanan dan minuman yang dikonsumsi harus memenuhi syarat kesehatan (Pohan, 2009). Makanan dan minuman yang tidak memenuhi persyaratan kesehatan akan menimbulkan gangguan kesehatan seperti diare, kolera, disentri, demam tifoid dan keracunan makanan (Yunaenah, 2009). Setiap tahun di dunia terjadi peningkatan yang signifikan pada kasus penyakit yang disebabkan oleh bakteri pada makanan (foodborne diseases) (Rossi et al., 2012). Studi kasus di Amerika Serikat terjadi hampir 38,6 juta kasus penyakit akibat penyebaran penyakit bawaan makanan (foodborne diseases) (Ojima et al., 2002). Data Kemenkes (2017) di 3 provinsi Indonesia, kasus diare pada tahun 2016 dengan Case Fatality Rate (CFR) mencapai 3.04\% dengan 6 orang meninggal dari 198 kasus. Salah satu penyebab tingginya kasus foodborne diseases adalah kebersihan peralatan makanan (Donofrio et al., 2012)

Kebersihan peralatan makan merupakan salah satu aspek dalam hygiene dan sanitasi makanan. Proses pencucian peralatan makan yang benar akan berdampak pada hygiene dan sanitasi yang baik. Spons cuci piring umumnya digunakan untuk menghilangkan sisa makanan. Sisa makanan yang terdapat pada spons akan mendukung lingkungan bakteri untuk tumbuh. Spons cuci piring adalah tempat ideal untuk pertumbuhan mikroba patogen, seperti bakteri dan virus. Bakteri patogen yang dapat tumbuh baik di spons cuci piring adalah Eschericia coli, Salmonella, Klebsiella pneumoniae, dan Enterobacter. Spons yang 
terkontaminasi dapat mengkontaminasi peralatan makan, sehingga menyebabkan penularan penyakit bawaan makanan (foodborne diseases) (Ikawa \& Rossen, 1999).

Penelitian bakteri pada spons cuci piring pada pengusaha makanan seperti restauran, hotel, kedai kue, dan cafetaria didapatkan hasil $19.6 \%$ mengandung Pseudomonas sp., $11.5 \%$ mengandung Enterobacteriaceae, $11.1 \%$ mengandung Bacillus, 10,6\% mengandung Micrococcus, $7.8 \%$ mengandung Streptococcus dan 6\% mengandung Lactobacillus (Wolde \& Bacha, 2016). Berdasarkan penelitian Obi dan Ndukwu (2016) di Ikwuano, Nigeria melaporkan dari total 60 sampel spons cuci piring, sebanyak 100\% mengandung Escherichia coli, 43.3\% mengandung Pseudomonas aeruginosa, dan $13.3 \%$ mengandung Staphylococcus aureus. Di Indonesia penelitian yang di lakukan oleh Gaffar dkk., (2014) menggunakan metode PCR-RFLP, dilaporkan ada 4 populasi bakteri yang hidup pada spons basah, dan teridentifikasi salah satu mikroba yang tumbuh adalah Escherichia coli yang merupakan bakteri patogen.

Penelitian terkait isolasi bakteri patogen dalam spons belum pernah dilakukan di Indonesia. Oleh karena itu penulis tertarik untuk melakukan identifikasi bakteri patogen yang terkandung pada spons cuci piring penjual makanan. Penelitian ini diharapkan dapat mengurangi adanya transmisi bakteri ke makanan dengan teridentifikasinya bakteri patogen yang terkandung dalam spons.

\section{METODE}

Penelitian ini merupakan penelitian dengan metode deskriptif dengan desain yang digunakan untuk pengumpulan sampel adalah Cross sectional. Penelitian ini dilaksanakan bulan Februari-Maret 2018 di Laboratorium Bakteriologi STIKes Mitra Keluarga dan lokasi pengambilan sampel di Pasar Margahayu, Bekasi Timur. Spons cuci piring basah di kumpulkan dari 10 pedagang makanan di Pasar Margahayu, Bekasi Timur. Spons basah yang diambil dari penjual makanan disimpan dalam plastik klip. Kemudian Spons digunting dengan gunting steril dengan ukuran $\pm 0.5 \mathrm{~cm}^{2}$. Spons yang sudah digunting direndam ke dalam $5 \mathrm{ml}$ buffer pepton water di dalam tabung reaksi. Tabung reaksi yang sudah berisi spons di shaker selama 5 menit dengan suhu $37{ }^{\circ} \mathrm{C}$. Tabung reaksi yang sudah berisi spons di inkubasi selama 24 jam pada suhu $37{ }^{\circ} \mathrm{C}$ (Gaffar dkk., 2014). Isolat yang tumbuh pada media buffer pepton water di lakukan pengenceran hingga pengenceran $10^{-2}$, dan dilakukan penanaman pada media MCA, SSA, dan MSA. Koloni yang tumbuh di lakukan pewarnaan gram dan pengujian biokimia. Uji biokimia yang dilakukan adalah uji TSIA, uji MR, uji VP, uji katalase, uji Indol, dan motilitas.

HASIL

Tabel 1. Hasil Uji Biokimia

\begin{tabular}{|c|c|c|c|c|c|c|}
\hline Uji Biokimia & $\begin{array}{c}\text { Putih } \\
\text { transparan } \\
\text { pada media } \\
\text { MCA }\end{array}$ & $\begin{array}{c}\text { Merah pada } \\
\text { media SSA }\end{array}$ & $\begin{array}{c}\text { Putih bulat } \\
\text { besar pada } \\
\text { media } \\
\text { MCA }\end{array}$ & $\begin{array}{c}\text { Putihbulat } \\
\text { kecil pada } \\
\text { media MCA }\end{array}$ & $\begin{array}{c}\text { Putih, zona } \\
\text { kuning } \\
\text { pada media } \\
\text { MSA }\end{array}$ & $\begin{array}{c}\text { Putih } \\
\text { transparan } \\
\text { bulat kecil } \\
\text { pada media } \\
\text { MCA }\end{array}$ \\
\hline \multicolumn{7}{|l|}{ TSIA } \\
\hline \multirow[t]{2}{*}{ - Gas } & $\mathrm{K} / \mathrm{K}$ & $\mathrm{K} / \mathrm{K}$ & $\mathrm{K} / \mathrm{K}$ & $\mathrm{M} / \mathrm{M}$ & $\mathrm{M} / \mathrm{K}$ & $\mathrm{K} / \mathrm{K}$ \\
\hline & + & + & + & - & - & + \\
\hline - $\mathrm{H}_{2} \mathrm{~S}$ & + & - & - & - & - & - \\
\hline MR & + & - & + & - & + & - \\
\hline VP & - & + & - & - & - & + \\
\hline Indol & + & - & + & - & - & - \\
\hline Motilitas & + & + & + & + & - & + \\
\hline Katalase & - & + & + & - & + & + \\
\hline \multicolumn{7}{|l|}{ Uji gula-gula } \\
\hline - Glukosa & $+/ g$ & $+/ g$ & $+/ g$ & $+/ g$ & $+/ g$ & $+/ g$ \\
\hline - Laktosa & $+/ g$ & $+/ g$ & + & $+/ g$ & + & $+/ g$ \\
\hline - Maltosa & $+/ g$ & $+/ g$ & $+/ g$ & $+/ g$ & $+/ g$ & $+/ g$ \\
\hline
\end{tabular}




\begin{tabular}{cccccccc}
\hline$\bullet$ Sukrosa & $+/ \mathrm{g}$ & $+/ \mathrm{g}$ & $+/ \mathrm{g}$ & $+/ \mathrm{g}$ & - & $+/ \mathrm{g}$ \\
$\bullet$ Manitol & + & $+/ \mathrm{g}$ & + & $+/ \mathrm{g}$ & - & $+/ \mathrm{g}$ \\
& & $\begin{array}{c}\text { Proteus } \\
\mathrm{sp}\end{array}$ & E. aerogenes & E. coli & $\begin{array}{c}P . \\
\text { aeroginosa }\end{array}$ & S. aureus & E. aerogenes \\
\hline
\end{tabular}

Berdasarkan Tabel 1, hasil uji biokimia dari koloni yang tumbuh pada media MCA, SSA, dan MSA menunjukkan kecurigaan terhadap koloni berwarna putih transparan adalah Proteus sp. koloni putih transparan bulat kecil adalah Enterobacter aerogenes, putih bulat besar adalah Escherichia coli, putih bulat kecil adalah Pseudomonas aeroginosa, koloni merah pada media SSA adalah Enterobacter aerogenes, dan koloni putih dengan zona kuning adalah Staphylococcus aureus.

Presentase bakteri yang terdapat pada spons cuci piring terdapat pada Tabel 2. Berdasarkan Tabel 2, persentase isolat $S$. aureus dari 10 spons sebanyak $80 \%$.

Tabel 2. Presentase isolat bakteri yang terdapat pada spons cuci piring

\begin{tabular}{lccc}
\hline \multicolumn{1}{c}{ Isolat } & $\begin{array}{c}\text { Jumlah spons yang } \\
\text { diamati }\end{array}$ & $\begin{array}{c}\text { Jumlah spons yang mengandung } \\
\text { bakteri }\end{array}$ & $\begin{array}{c}\text { Persen } \\
(\%)\end{array}$ \\
\hline Staphylococcus aureus & 10 & 8 & 80 \\
Enterobacter aerogenes & 10 & 7 & 70 \\
Pseudomonas aeruginosa & 10 & 2 & 20 \\
Escherichia coli & 10 & 2 & 20 \\
Proteus sp. & 10 & 1 & 10 \\
\hline
\end{tabular}

\section{PEMBAHASAN}

Kehadiran $S$. aureus pada spons bisa disebabkan karena adanya transmisi $S$. aureus dari tangan manusia yang merupakan habitat alaminya karena spons cuci piring digunakan melalui kontak langsung dengan tangan manusia (Kotula et al., 1997). Namun hasil penelitian Obi dan Ndukwu (2016) didapatkan hanya $13.3 \%$ sampel yang mengandung $S$. aureus. Hal ini disebabkan karena $S$. aureus memilki dinding sel yang sensitif terhadap surfaktan anionik yang ada di beberapa sabun cuci piring yang dapat berkontribusi pada inaktivasi mikroorganisme. Selain melalui tangan, media transmisi bakteri dapat melalui udara. Hal tersebut dibuktikan dengan hasil penelitian Tyagi \& Tyagi (2013), dari 80 dapur yang di uji kualitas udaranya, terdapat $50 \%$ mengandung S. aureus. Adanya S. aureus dalam spons cuci piring dapat menyebabkan penyebaran foodborne dissease dengan terjadinya keracunan stafilokoki. Kasus yang terjadi adalah kasus intoksikasi, yaitu tertelannya stafilokoki eneterotoksin yang dihasilkan oleh $S$. aureus ke dalam saluran pencernaan (Apriyadi, 2010).

Kehadiran E. coli pada spons cuci piring didapatkan sebanyak $20 \%$ dari 10 spons yang di isolasi pada media MCA. Persentase E. coli tersebut tidak sesuai dengan hasil penelitian yang didapatkan oleh Obi dan Ndukwu (2016), sebanyak 60 sampel spons cuci piring 100\% mengandung E. coli. Adanya E. coli pada spons cuci piring sesuai dengan penelitian Gaffar dkk., (2014) yang menggunakan metode PCR-RFLP, dilaporkan ada 4 populasi bakteri yang hidup pada spons basah, dan teridentifikasi salah satu mikroba yang tumbuh adalah E. coli yang merupakan bakteri patogen. Kehadiran E. coli dapat menjadi indikasi dari kontaminasi fekal pada air minum maupun makanan (Arnia \& Warganegara, 2013). Kontaminasi dari $E$. coli dapat berbahaya bagi kesehatan, terutama untuk populasi yang beresiko seperti bayi, lansia, dan orang yang mengalami penurunan kekebalan tubuh. Penyakit yang disebabkan oleh E. coli adalah gangguan gastroenteritis (Motarjemi et al., 2006).

Persentase yang didapatkan untuk spesies $P$. aeroginosa sebanyak $20 \%$ dari 10 spons cuci piring pada media MCA. Persentase $P$. aeroginosa tersebut sesuai dengan hasil penelitian yang didapatkan oleh penelitian Wolde dan Bacha (2016) sebanyak 201 spons cuci piring mengandung sebanyak 19.6\% Pseudomonas sp. Namun tidak sesuai dengan hasil penelitian Obi dan Ndukwu (2016), dari 60 sampel spons cuci piring didapatkan $43.3 \%$ mengandung $P$. aeruginosa. Menurut penelitian Tyagi \& Tyagi (2013), dari 80 dapur yang di uji kualitas udaranya, terdapat $20 \%$ mengandung $P$. aeruginosa. Hal tersebut menandakan bahwa transmisi $P$. aeruginosa dapat melalui udara. $P$. aeruginosa termasuk kedalam bakteri 
patogen oportunistik yang dapat menyebabkan keadaan invasif pada orang dengan tingkat imunitas yang rendah (Slama et al., 2011).

Belum ada studi kasus untuk keberadaan Proteus sp. dan E. aerogenes dalam spons cuci piring. Namun berdasarkan penelitian Protou (2015) Proteus sp. dan E. aerogenes ditemukan dalam sayuran mentah siap saji dengan persentase $20 \%$ dan $40 \%$. Menurut penelitian Tyagi \& Tyagi (2013), dari 80 dapur yang di uji kualitas udaranya, terdapat $70 \%$ mengandung Proteus sp. dan 2.5\% mengandung Enterobacter sp. Hal tersebut menandakan bahwa udara dapat menjadi salah satu media transmisi bakteri ke spons cuci piring. Proteus sp. dan E. aerogenes termasuk ke dalam golongan flora usus normal yang tidak menyebabkan penyakit, namun dapat menjadi patogen ketika pertahanan tumbuh seseorang sedang menurun (Kectum, 2000).

\section{KESIMPULAN}

Berdasarkan penelitian yang telah dilakukan dapat disimpulkan yaitu sampel spons cuci piring yang telah dilakukan pewarnaan Gram dan uji biokimia menunjukkan kecurigaan terhadap koloni berwarna putih transparan adalah Proteus sp. koloni putih transparan bulat kecil adalah Enterobacter aerogenes, putih bulat besar adalah Escherichia coli, putih bulat kecil adalah Pseudomonas aeroginosa, koloni merah pada media SSA adalah Enterobacter aerogenes, dan koloni putih dengan zona kuning adalah Staphylococcus aureus.

\section{REFERENSI}

Apriyadi, T. E. 2010 . Resiko Staphylococcus aureus pada Pangan Tradisional Siap Santap dan Evaluasi Keberadaannya dalam Nasi Uduk, Skripsi, Fakultas Teknologi Pertanian,Institut Pertanian Bogor, Bogor.

Arnia, \& Warganegara, E. 2013. Identifikasi Kontaminasi Bakteri Coliform pada Daging Sapi Segar yang Dijual di Pasar Sekitar Kota Bandar Lampung. MAJORITY (Medical Journal of Lampung University). $2: 43-50$.

Donofrio, R. S., Bechanko, R., O'Malley, K., Chamauski, T., Bestervelt, L. L., \& Saha, R. 2012 . Are We Aware of Microbial Hotspots in Our Household?. J Environ Health 5 : 1-8.

Gaffar, S., Maksum, I. P., \& Julaeha, E. 2014. Identifikasi Populasi Bakteri dalam Spons Pencuci Piring dengan Metode PCR-RFLP. Chemica et Natura Acta , $2: 120-125$.

Ikawa, j., \& Rossen, J. 1999. Reducing Bacteria in Household Sponges. J Environ Health, 7 (14) : 18-22.

Kectum, A. 2000. Microbiology Introduction for Health Profesionals Enteric. Medical Microbiology, Canada.

Kemenkes, RI. 2017. Profil Kesehatan Indonesia Tahun 2016. Kemenkes RI, Jakarta.

Kotula, K. L., Kotula, A. W., Rose, B. F., \& Camp, M. 1997. Reductions of Aqueous Chlorie by Organic Material. J Food Prod, 60 : 276-282

Motarjemi, Y., Moarefi, A., \& Jacob, M. 2006 . Penyakit Bawaan Makanan Fokus Pendidikan Kesehatan. EGC, Jakarta.

Obi, C. N., \& Ndukwu, C. C. 2016. Microbiological Examination of Household Kitchen Sponges from Three Communities in Ikwuano L.G.A, Umuahia, Abia State Nigeria. British Microbiol Res J. 11 : 1-9.

Ojima, M., Toshima, Y., Koya, E., Ara, K., Tokuda, H., Kawai, S., et al., 2002. Hyigene Measures Considering Actual Distributions of Microorganism in Japanese Household. J App Microbiol. 93 : 800-809.

Pohan, D. 2009. Pemeriksaan Escherichia coli pada Usapan Peralatan Makan yang Digunakan Oleh Pedagang Makanan di Pasar Pestisah Medan Tahun 2009. Skripsi, Universitas Sumatera Utara, Fakultas Kesehatan Masyarakat, Medan.

Protou, J. 2015. Pola Bakteri Aerob Ptogen yang Diisolasi dari Sayur Mentah Siap Saji yang Dijual di Rumah Makan Kawasan Boulevard Manado. Jurnal e-Biomedik (eBm). 3 : 594-599.

Rossi, E. M., Scapin, D., Grando, W. F., \& Tondo, E. C. 2012. Microbiological Contamination and Disinfection Procedurs of Kitchen Sponges Used in Food Services. Food and Nutritio Sciences. 3 : 975-980.

Slama, Karim, B., Skander, G., Ahlem, J., Mariem, M., \& Chedila, F. 2011. Epidemiology of Pseudomonas aeroginosa in Intensive Care Unit and Otolaryngology Department of a Tunisian Hospital. African $J$ 
Microbiol Res. 5.

Tyagi, P. K., \& Tyagi, S. 2013. Bacterial Contamination in Kitchens of Rural and Urban Areas in Meerut District of Utter Pradesh (India). African J Microbiol Res. 17 : 2020-2026.

Wolde, T., \& Bacha, K. 2016. Microbiological Safety of Kitchen Sponges Used in Food Establishment. Int J Food Science . $7: 1-7$.

Yunaenah. 2009. Kontaminasi E.coli pada Makanan Jajanan di Kantin Sekolah Dasar Wilayah Jakarta Pusat Tahun 2009. Tesis, Universitas Indonesia, Fakultas Kesehatan Masyarakat, Depok 